\title{
OPEN Modified plant architecture integrated with liquid fertilizers improves fruit productivity and quality of tomato in North West Himalaya, India
}

Avinash Chandra Rathore ${ }^{1 凶}$, Harsh Mehta ${ }^{1}$, J. Jayaprakash ${ }^{1}$, Charan Singh $^{1}$, Anand Kumar Gupta ${ }^{1}$, Pawan Kumar ${ }^{1}$, Sadikul Islam ${ }^{1}$, Saswat Kumar Kar ${ }^{1}$, Sridhar Patra ${ }^{1}$, Lekh Chand $^{1}$, Vijay Kumar Doharey ${ }^{1,2}$, Prabhat Ranjan Ojasvi ${ }^{1}$, Ram Swaroop Yadav ${ }^{1}$ \& M. Madhu ${ }^{1}$

India produces around 19.0 million tonnes of tomatoes annually, which is insufficient to meet the ever-increasing demand. A big gap of tomato productivity $\left(72.14 \mathrm{tha}^{-1}\right)$ between India $\left(24.66 \mathrm{t} \mathrm{ha}^{-1}\right)$ and the USA $\left(96.8 \mathrm{t} \mathrm{ha}^{-1}\right)$ exist, which can be bridged by integrating trellis system of shoot training, shoot pruning, liquid fertilizers, farmyard manure, and mulching technologies. Therefore, the present experiment was conducted on tomato (cv. Himsona) during 2019-2020 at farmers' fields to improve tomato productivity and quality. There were five treatments laid in a randomized block design (RBD) with three replications; $T_{1}$ [Farmer practice on the flatbed with RDF @ $N_{120}: P_{60}: K_{60}+F Y M$ @6.0 $t$ ha ${ }^{-1}$ without mulch $], T_{2}\left[T_{1}+\right.$ Polythene mulch (50 microns)], $T_{3}$ [Tomato plants grown on the raised bed with polythene mulch + FYM @ $8.0 \mathrm{t} \mathrm{ha}^{-1}+$ Single shoot trellis system + Side shoot pruning + Liquid Fertilizer $\left(\mathrm{LF}_{1}-\mathrm{N}_{19}: \mathrm{P}_{19}: \mathrm{K}_{19}\right)$ @ $2.0 \mathrm{~g} \mathrm{l}^{-1}$ for vegetative growth + Liquid Fertilizer $\left(\mathrm{LF}_{2}-\mathrm{N}_{0}: \mathrm{P}_{52}: \mathrm{K}_{34}\right)$ @ $1.5 \mathrm{~g} \mathrm{l}^{-1}$ for improving fruit quality], $\mathrm{T}_{4}$ [Tomato plants grown on the raised bed with polythene mulch $+\mathrm{FYM}$ @ $8.0 \mathrm{t} \mathrm{ha}^{-1}+$ Single shoot trellis system + Side shoot pruning $+\mathrm{LF}_{1}$ @ $4.0 \mathrm{gl}^{-1}+\mathrm{LF}_{2}$ @ $\left.3.0 \mathrm{~g} \mathrm{l}^{-1}\right]$, and $\mathrm{T}_{5}$ [Tomato plants grown on the raised bed with polythene mulch + FYM @ $10.0 \mathrm{t} \mathrm{ha}^{-1}+$ Single shoot trellis system + Side shoot pruning + $\mathrm{LF}_{1}$ @ $6.0 \mathrm{~g} \mathrm{l}^{-1}+\mathrm{LF}_{2}$ @ $4.5 \mathrm{~g} \mathrm{l}^{-1} \mathrm{]}$. The results revealed that tomato plant grown on the raised beds with polythene mulch, shoot pruning, trellising, liquid fertilizers, and farmyard manure (i.e., $\mathrm{T}_{5}$ ) recorded higher shoot length, dry matter content, and tomato productivity by $20.75-141.21,18.79-169.4$, and $18.89-160.87 \%$ as compared to $T_{4}-T_{1}$ treatments, respectively. The $\mathrm{T}_{5}$ treatment also recorded the highest water productivity $\left(28.39 \mathrm{~kg} \mathrm{~m}^{-3}\right)$, improved fruit qualities, net return $(10,751$ USD ha-1), benefit-cost ratio (3.08), microbial population, and enzymatic activities as compared to other treatments. The ranking and hierarchical clustering of treatments confirmed the superiority of the $\mathrm{T}_{5}$ treatment over all other treatments.

The tomato (Solanum lycopersicum L.), a member of the family Solanaceae is one of the world's most consumed vegetable crops. It is one of the most important global vegetable crops because of its diversified uses, taste, colour, and high nutritive values. It is grown in tropical to temperate climatic zones, but tomatoes' actual yield in the tropics is generally low compared to the temperate regions. The global tomato production is 182.3 million tonnes from about 5.0 million ha area. China is the leading tomato producer (61.63 million tons from 1.03 million ha), followed by India (19.38 from 0.79). Based on tomato productivity (Table 1), the United States of America ranks first (96.8 $\left.\mathrm{t} \mathrm{ha}^{-1}\right)$, followed by Turkey (68.86), China (59.25), Egypt (40.97), and India (24.66 $\left.\mathrm{t} \mathrm{ha}^{-1}\right)$. However, India is the second-largest tomato producing country in the world after China and contributes $10.63 \%$ of global tomato production from $15.72 \%$ of the global tomato area ${ }^{1}$. Among the leading states, Andhra Pradesh recorded the highest tomato productivity (44.50), followed by Himachal Pradesh (42.88), Uttar Pradesh (39.62), and Karnataka (32.40). Tomato availability of India rose to $14.33 \mathrm{~kg} \mathrm{capita}^{-1} \mathrm{year}^{-1}\left(39.33 \mathrm{~g} \mathrm{capita}^{-1} \mathrm{day}^{-1}\right)$ in 2018 from

${ }^{1}$ ICAR-Indian Institute of Soil and Water Conservation, 218 Kaulagarh Road, Dehradun 248195, Uttarakhand, India. ${ }^{2}$ Krishi Vigyan Kendra, Jyolokot, Nainital, Uttarakhand, India. ${ }^{凶}$ email: rathoreac.iiswc@gmail.com 


\begin{tabular}{|l|l|l|r|r|l|l|l|l|}
\hline \multirow{2}{*}{ Countries } & \multicolumn{3}{|l|}{ Area $(\mathbf{m}$ ha) } & \multicolumn{3}{|c|}{ Production $(\mathbf{m t})$} & \multicolumn{2}{l|}{ Productivity } \\
ha $\left.^{-1}\right)$ & \multicolumn{2}{l|}{$\begin{array}{l}\text { Global share } \\
(\mathbf{\%})\end{array}$} \\
\cline { 2 - 10 } & $\mathbf{2 0 1 0}$ & $\mathbf{2 0 1 8}$ & $\mathbf{2 0 1 0}$ & $\mathbf{2 0 1 8}$ & $\mathbf{2 0 1 0}$ & $\mathbf{2 0 1 8}$ & $\mathbf{2 0 1 0}$ & $\mathbf{2 0 1 8}$ \\
\hline China & 0.871 & 1.040 & 41.88 & 61.63 & 48.08 & 59.25 & 28 & 33.81 \\
\hline India & 0.865 & 0.786 & 16.83 & 19.38 & 19.46 & 24.66 & 11 & 10.63 \\
\hline Turkey & 0.304 & 0.176 & 10.05 & 12.15 & 33.06 & 68.86 & 7 & 6.66 \\
\hline USA & 0.159 & 0.137 & 12.90 & 12.61 & 81.13 & 96.80 & 9 & 5.92 \\
\hline Egypt & 0.216 & 0.161 & 8.55 & 6.62 & 39.58 & 40.97 & 6 & 3.63 \\
\hline Total & 2.42 & 2.33 & 90.21 & 111.30 & 37.35 & 47.87 & 61 & 61.65 \\
\hline Global & 4.58 & 5.00 & 150.51 & 182.30 & 32.86 & 36.46 & 100 & 100 \\
\hline
\end{tabular}

Table 1. Global area, production, and productivity of tomato in 2018. Source: FAOSTAT, 2019.

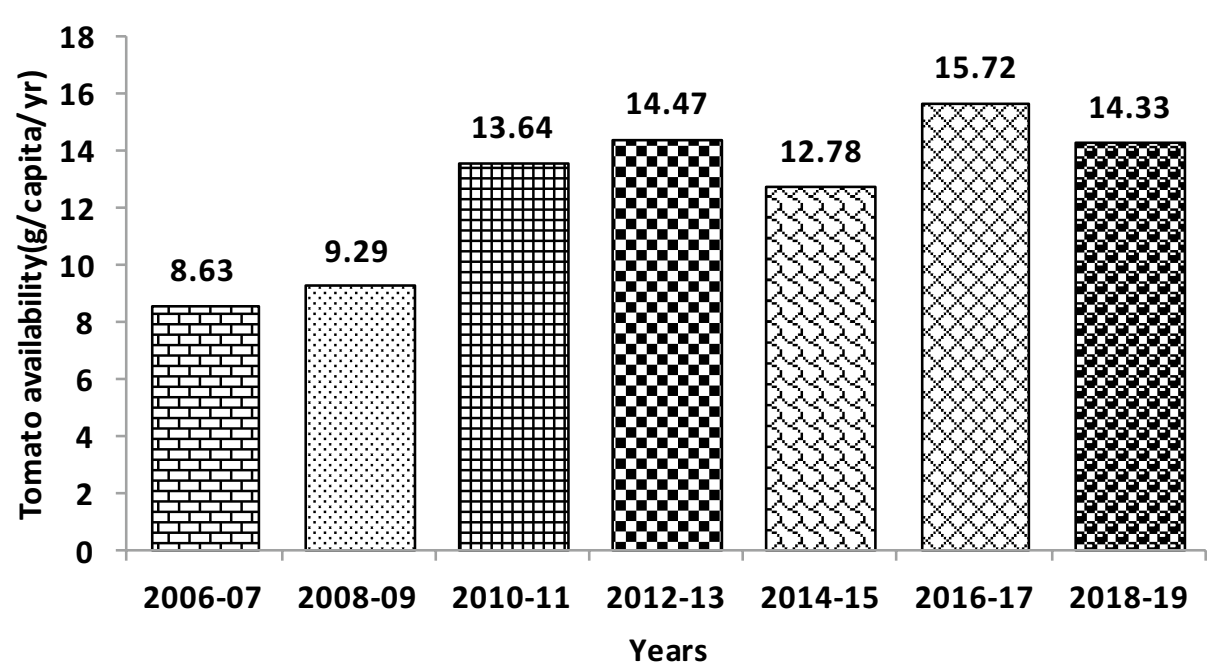

Figure 1. Tomato availability in India (Kg capita ${ }^{-1}$ year $\left.^{-1}\right)$. Source FAOSTAT 2019 and NHB database 2018.

$8.63 \mathrm{~kg} \mathrm{capita}^{-1}$ year $^{-1}$ in 2006 with a rise of almost $66.0 \%$ (Fig. 1), which is also far below than tomato availability of $82.83 \mathrm{~kg} \mathrm{capita}^{-1}$ year $^{-1}\left(227.0 \mathrm{~g} \mathrm{capita}^{-1}\right.$ day $\left.^{-1}\right)$ of Italy due to lower tomato productivity of our country ${ }^{2}$. Tomato productivity of India has been realized as high as 170.0 tha $^{-1}$ in polyhouse condition ${ }^{3}$ which indicate that the potential of tomato productivity under protected cultivation (poly houses/net houses) can be harnessed outside the polyhouse/net house at farmers field, which will not only improve the tomato productivity but also increase national productivity $\left(>100 \mathrm{t} \mathrm{ha}^{-1}\right)$ in open conditions $\mathrm{s}^{4}$ by the plant architecture modification such as single shoot training (trellising), aside shoot pruning, mulching, and application of liquid fertilizers in India.

The major demerit of farmer practice of tomato cultivation (tomato plant without the support and pruning) is that tomato plant becomes more bushy, branchy, compact and restrict vertical growth $(<1.0 \mathrm{~m})$ in tomato which interrupt proper ventilation/aeration inside the plant leads poor growth and attracts more pest due to higher humidity inside the plant. The single shoot trellis system of training aims to support plant growth in a desired shape/direction, which provides a better opportunity to harvest solar energy vertically to increase flowering and fruit yield in tomatoes. It also allows efficient air circulation, easy to practice cultural operations viz; weeding, hoeing, watering, harvesting, inspection of the field, prevent lodging, fruit rotting, liquid fertilizers application, etc $^{5,6}$. This offers an opportunity to develop a training system with poles, wire, and threads to train the plants in a required shape into a trellis system of training, which will improve the duration of the flowering and fruiting total length of the main tomato shoot in addition to a stable support. In this practice, pruning parts of the plants like non-productive shoots, diseased leaves, and fruits are removed to regulate canopy and minimize photosynthates wastage. Tomato plants can be pruned severely without affecting the tomato yield ${ }^{7,8}$. Besides, the application of farmyard manure (FYM) also adds organic matter to the soil, which improves microbial population and enzymatic activities.

The current practice of applying solid fertilizers spoils soil health and decreases crop productivity in the long run compared to liquid fertilizer. Liquid fertilizer is a solution containing one or more nutrients essential to the plant, and its application can be arranged according to the plants' requirement as plants quickly absorb the nutrients and improve plant health, yields, fruit qualities (colour, carotenoid, vitamin C, etc.) and profitability. The nutrient use efficiency of nitrogen, phosphorus, and potash in India is 50, 10, and 40\%, respectively, besides ill effects on soil health of major solid fertilizers (urea, diammonium phosphate, and muriate of potash). In other words, $50 \%$ of nitrogen, $90 \%$ phosphorus, and $60 \%$ potash is going out of the system as runoff or escaping into 


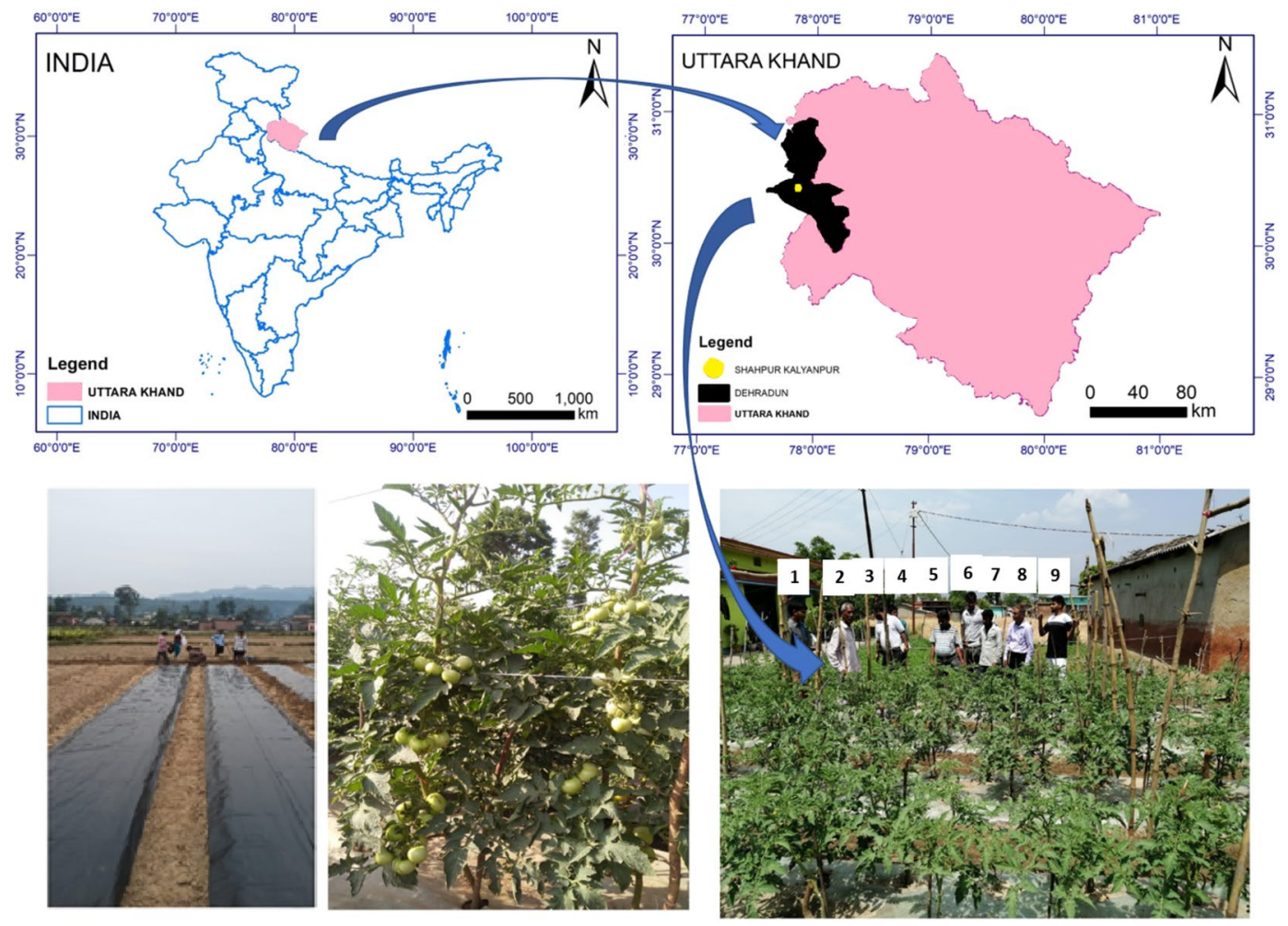

Figure 2. Location map of the experimental site. This map was prepared using Arc GIS 10.3. Humans appearing in the above figure are members of research team marked as 3, 5, 6, 8 and 9 as well as farmers $(1,2,4$ and 7). Informed consent for online publication of information and participation has been obtained from all the farmers.

the atmosphere, causing other problems in water bodies ${ }^{9,10}$. It is an alternative to soil nutrient management and can be a better option for commercial use in horticulture as it provides nutrients as per the needs of crop ${ }^{11,12}$.

Therefore, this study aimed at applying plant architectural modification (pruning, trellising/training), and use of liquid fertilizers for open conditions at farmer's fields to determine the impact on the performance of fruit yield and quality of tomato.

\section{Materials and methods}

Field location and descriptions. The experiment was conducted on an indeterminate tomato cv. Himsona during March-July 2019-2020 in the tribal belt of Shahpur-Kalyanpur in Tehsil Vikasnagar of district Dehradun, Uttarakhand. This research involving tomato cv. Himsona complies with relevant institutional, national, and international guidelines and legislation and it does not involve collection of specific plant materials from the experimental area. This variety was released, identified and notified through All India Coordinated Research Project on Vegetable Crops (AICRP-VC) in 2009, and is in public domain in India. The experimental site is situated in the Indian Sub-Himalayan region at an altitude of $517 \mathrm{~m}$ above mean sea level between $30^{\circ} 24^{\prime} 27^{\prime \prime} \mathrm{N}$ latitude and $77^{\circ} 47^{\prime} 50^{\prime \prime}$ E longitude (Fig. 2). The climate is humid subtropical, average annual rainfall of $1600 \mathrm{~mm}$ (approx. 80\% during June-September) with a monsoonal rainfall pattern, mean monthly maximum and minimum temperature ranging from 19.0 to $37.6^{\circ} \mathrm{C}$ in summer and $3.6-24.0^{\circ} \mathrm{C}$ in the winter. Standard procedures were followed to determine the initial soil physical and chemical parameters replicated thrice for each treatment. The soil is classified as sandy loam texture. The soil $\mathrm{pH}$ ranged from $6.6-7.5$, bulk density, $1.41-1.46 \mathrm{Mg} \mathrm{m}^{-3}$, soil organic carbon, $0.7-0.8 \%$, total nitrogen, $242-265 \mathrm{~kg} \mathrm{ha}^{-1}$, available phosphorus, $9.5-10.8 \mathrm{~kg} \mathrm{ha}^{-1}$, and available potassium, $98.6-114.6 \mathrm{~kg} \mathrm{ha}^{-1}$. Analysis of variance of these soil properties did not show any significant difference $(\mathrm{p} \leq 0.05)$ among the samples collected from different treatment plots indicating a fairly homogeneous initial soil unit.

Details of the experiment. Seeds of indeterminate tomato (cv. Himsona) were sown in the first week of February during 2019 and 2020. About one-month-old seedlings were transplanted in the field in a paired rows system $(65 \mathrm{~cm} \times 45 \mathrm{~cm})$ on 1.0 -m-wide and $15 \mathrm{~cm}$ raised bed with a $30 \mathrm{~cm}$ channel between two beds to facilitate cultural operations such as weeding, training, pruning, pesticides spraying, harvesting, etc. The plant density maintained during both years was 34,188 plants ha ${ }^{-1}$. The black polythene mulch (50 microns) was laid on beds before tomato transplanting. The axillary shoots were removed after 25 days after transplanting, and after that, regular pruning of axil shoots was done at weekly intervals. The trellising of tomato seedlings (bamboo sticks/ iron pole) was started after one month of tomato transplanting in the field. Plants were trained along the plas- 


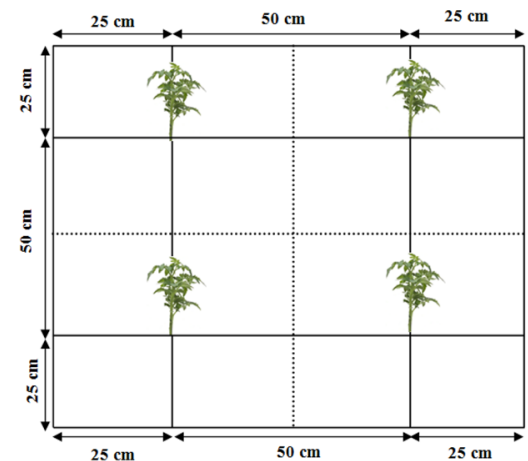

a

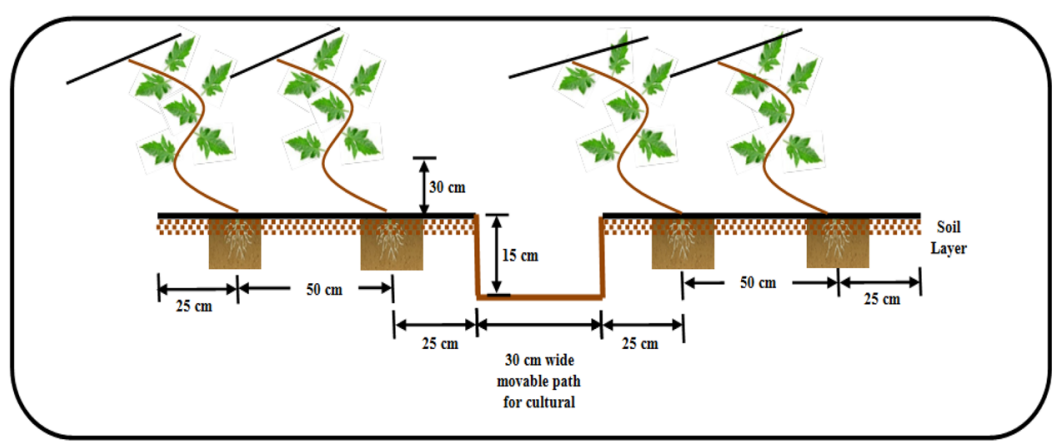

$\mathrm{b}$

Figure 3. (a) Experimental layout of tomato field. (b) Planting design of tomato.

tic thread tied to a galvanized iron wire stretched in a trellis system along the bed (Fig. 3 ). The tomato plants were irrigated manually using a flexible rubber pipe based on visual interpretation of plant symptoms and soil moisture conditions during March-June (2019-2020). In the initial phases of plant establishment (March 2019), each plant received approximately $200 \mathrm{ml}$ per day and was increased to $800 \mathrm{ml}$ per day towards the termination phase. The irrigation practice traditionally followed by local farmers was based on the visual interpretation of soil moisture and crop wilting stage. The water amount was determined using knowledge of the local farmers ${ }^{13}$. The irrigation was applied from day 1 (transplanting day) up to mid of June as per the need for different treatments. However, irrigation was withdrawn after monsoon arrival in June for both years.

Recommended doses of fertilizers (RDF) of nitrogen, phosphorus, and potash @ $\mathrm{N}_{120}: \mathrm{P}_{60}: \mathrm{K}_{60} \mathrm{~kg} \mathrm{ha}^{-1}$ were applied as per the recommended procedure. $\mathrm{N}_{60}: \mathrm{P}_{60}: \mathrm{K}_{60} \mathrm{~kg} \mathrm{ha}^{-1}$ was applied as basal dose, remaining $\mathrm{N}_{60} \mathrm{~kg}$ was applied in split doses $\left(\mathrm{N}_{30}\right.$ and $\left.\mathrm{N}_{30}\right)$ of 20 and 60 days after transplanting in the field manually. Two formulations of liquid fertilizers $\left(\mathrm{N}_{19}: \mathrm{P}_{19}: \mathrm{K}_{19}\right)$ and $\left(\mathrm{N}_{0}: \mathrm{P}_{52}: \mathrm{K}_{34}\right)$ were applied in which $\left(\mathrm{N}_{19}: \mathrm{P}_{19}: \mathrm{K}_{19}\right)$ was applied @ 2.0, 4.0, and $6.0 \mathrm{~g} \mathrm{l}^{-1}$ at 15-20 days intervals for maintaining vegetative growth of tomato from transplanting in the field to final fruit harvesting time whereas second liquid fertilizer formulation $\mathrm{N}_{0}: \mathrm{P}_{52}: \mathrm{K}_{34}$ applied @ 1.5, 3.0 and $4.5 \mathrm{~g} \mathrm{l}^{-1}$ after fruit initiation at 15-20 days intervals after flower initiation for yield and quality improvement of tomato fruits. The details of treatments studied on tomato plants are as follows:

\begin{tabular}{|l|l|}
\hline $\mathrm{T}_{1}$ & $\begin{array}{l}\text { Farmer practice on the flatbed with RDF @ } \mathrm{N}_{120}: \mathrm{P}_{60}: \mathrm{K}_{60}+\mathrm{FYM} @ 6.0 \mathrm{t} \\
\text { ha-1 without mulch }\end{array}$ \\
\hline $\mathrm{T}_{2}$ & $\mathrm{~T}_{1}+$ Polythene mulch $(50 \mathrm{micron})$ \\
\hline $\mathrm{T}_{3}$ & $\mathrm{RBPM}+\mathrm{FYM} @ 8.0 \mathrm{t} \mathrm{ha}^{-1}+\mathrm{SSTS}+\mathrm{SSP}+\mathrm{LF}_{1} @ 2.0 \mathrm{~g} \mathrm{l}^{-1}+\mathrm{LF}_{2} @ 1.5 \mathrm{gl}^{-1}$ \\
\hline $\mathrm{T}_{4}$ & $\mathrm{RBPM}+\mathrm{FYM} @ 8.0 \mathrm{tha}^{-1}+\mathrm{SSTS}+\mathrm{SSP}+\mathrm{LF}_{1} @ 4.0 \mathrm{~g} \mathrm{l}+\mathrm{LF}_{2} @ 3.0 \mathrm{~g} \mathrm{l} \mathrm{l}^{-1}$ \\
\hline $\mathrm{T}_{5}$ & $\begin{array}{l}\mathrm{RBPM}+\mathrm{FYM} @ 10.0 \mathrm{tha}^{-1}+\mathrm{SSTS}+\mathrm{SSP}+\mathrm{LF}_{1} @ 6.0 \mathrm{~g} \mathrm{l} \mathrm{l}^{-1}+\mathrm{LF}_{2} @ 4.5 \\
\mathrm{gl}^{-1}\end{array}$ \\
\hline
\end{tabular}

[RBPM (Tomato grown on raised bed with polythene mulch), RDF (Recommended dose of fertilizers), FYM (Farm Yard Manure) + SSTS (Single shoot trellis system), SSP (side shoot pruning) $+\mathrm{LF}_{1}$ (Liquid Fertilizer) supplied through $\left(\mathrm{N}_{19}: \mathrm{P}_{19}: \mathrm{K}_{19}\right)$ for vegetative growth (15-20 days interval) during entire growing period $+\mathrm{LF}_{2}$ (Liquid Fertilizer) supplied through $\left(\mathrm{N}_{0}: \mathrm{P}_{52}: \mathrm{K}_{34}\right)$ after fruit formation (15-20 days interval) up to harvesting of fruits].

Estimation of tomato yield and fruit quality parameters. The data on plant height/shoot length, growing duration, fruit weight, fruit yield, carotenoid, vitamin C, and lycopene contents were recorded during the growing phase based on five tagged tomato plants in each treatment. The shoot length $(\mathrm{m})$ was measured with measuring tape at the time of final fruit harvest, fruit weight at every harvest, and summed to calculate total yield per plant in tagged plants of tomato. The growing duration was calculated from day one to the last day of fruit harvesting, expressed as days. The $50 \mathrm{~g}$ sample of leaves, stem/shoots of tomato was collected from tagged plants and placed in the oven at $60.0^{\circ} \mathrm{C}$ for constant weight to calculate dry matter contents in leaves/shoots of tomato plants $\left(\mathrm{kg} \mathrm{plant}^{-1}\right)$. The plant materials of tomato variety 'Himsona' have been used to estimate the dry matter content under different treatments based on the average of 5 plants each. The tagged tomato plants were uprooted after 90 days when they achieved full maturity. The leaves, stem/shoots were sampled to obtain $50 \mathrm{~g}$ samples from each plant. The fruit quality parameters like carotenoid, vitamin $\mathrm{C}$, and lycopene content were analyzed as per the standard procedures ${ }^{14}$. The experiments conducted involving different experimental protocols were approved by Prioritization, Monitoring and Evaluation (PME) cell and Head of the Institution (ICAR-Indian Institute of Soil and Water Conservation), 218 Kaulagarh Road, Dehradun, Uttarakhand. It is stated that all methods have been conducted according to the standard guidelines and regulations. Water use efficiency (WUE) or water productivity (WP) was calculated as the ratio of tomato yield and water applied during the entire growth period from planting to the last day of watering. 


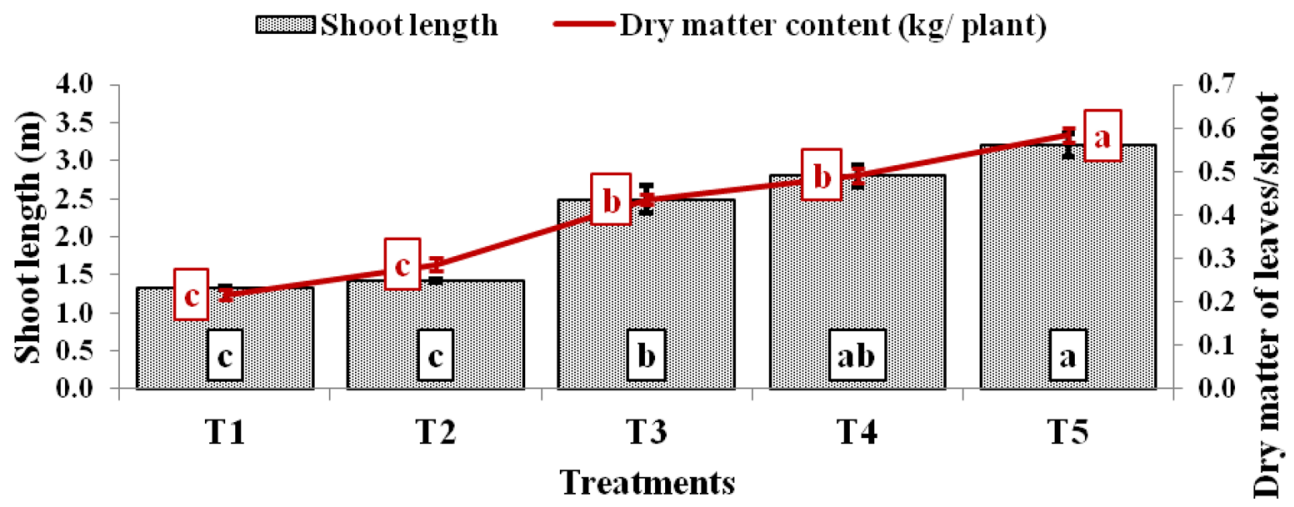

Figure 4. Shoot length $(\mathrm{m})$ and dry matter content of tomato under various treatments.

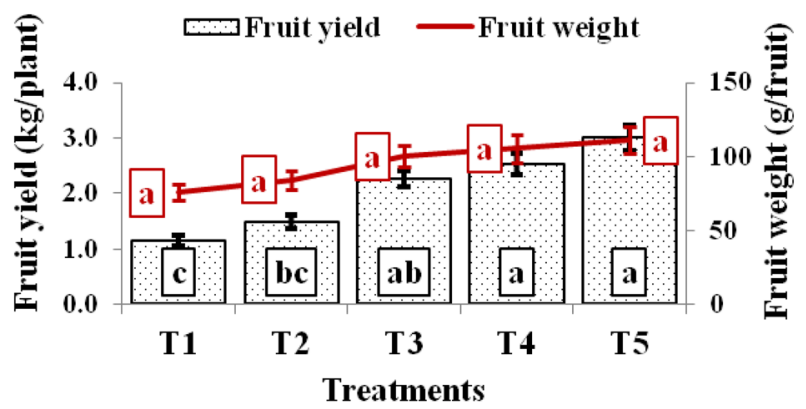

Figure 5. Average fruit weight and fruit yield of tomato under various treatments.

Analysis of nutrient status, microbial population and enzymatic activity of soil. Soil samples were taken with the help of Auger and analyzed in the laboratory. The collected samples were air-dried and ground to pass through a $2 \mathrm{~mm}$ sieve. Soil parameters were measured following standard methods viz; soil organic carbon $(\mathrm{OC})^{15}$, total nitrogen ${ }^{16}$, soil $\mathrm{pH}^{17}$. The available $\mathrm{P}$ was determined color-diametrically by the Olsen method and extracted $\mathrm{K}$ by flame photometry. Microbial analysis of soil was carried out following standard procedures. The total microbial counts were analyzed by the standard pour plate technique. Soil microbial population count was performed using serial dilution method ${ }^{17}$ and spread on different agar mediums viz. nutrient agar (M001) for bacteria, potato dextrose agar (M096) for fungi, and actinomycetes specific agar (M490) for actinomycetes. The microbial count (population) was expressed as colony-forming units $\mathrm{g}^{-1}$ ( $\mathrm{cfu}^{-1}$ soil) of dry soil. Soil dehydrogenase activity (DHA) was determined by $24 \mathrm{~h}$ of incubation, followed by a pink color intensity measured by spectrophotometer ${ }^{18,19}$. The $\beta$-glucosidase activity ${ }^{20}$ and phosphatase assay ${ }^{21}$ were determined by following standard procedures.

Statistical analysis. The experiment was laid in a randomized block design (RBD) with 3 replications. The data were analyzed using analysis of variance (ANOVA), assuming null hypothesis that all treatments' effect is equal. The post hoc analysis for pairwise treatment analysis was done using Tukey's Honest Test at $p=0.05$ level of significance. The relationship between parameters was analysed using Pearson's correlation coefficient for all the attributes like shoot length, crop duration, dry matter content in shoots, average fruit weight, fruit yield per plant, water use efficiency, vitamin C, lycopene content, and carotenoid ${ }^{22}$. Further, principal component analysis (PCA) was carried out to eliminate collinearity among growth, fruit production, quality, microbial population, enzymatic activities, and treatment ranking. The hierarchical cluster analysis of treatments using the Euclidean distance method was also performed with principal components (PC) as input instead of all the parameters studied because all variables were highly correlated.

\section{Results and discussion}

Growth parameters and fruit yield attributes. The shoot length, dry matter, fruit weight, and tomato yield varied significantly among the treatments (Figs. 4,5$)$. The maximum shoot length $(3.20 \mathrm{~m})$ and dry matter content $\left(0.584 \mathrm{~kg} \mathrm{plant}^{-1}\right)$ were observed in tomato plant grown on the raised bed, polythene mulch, regular pruning, trellising, and application of liquid fertilizers ( $\mathrm{T}_{5}$ treatment) followed by $\mathrm{T}_{4}(2.67$ and 0.491$), \mathrm{T}_{3}(2.49$ and 0.435$), \mathrm{T}_{2}(1.43$ and 0.287$)$ and lowest $\left(1.33 \mathrm{~m}\right.$ and $\left.0.217 \mathrm{~kg} \mathrm{plant}^{-1}\right)$ under $\mathrm{T}_{1}$ treatment in case of tomato. The shoot length and the dry matter recorded in $\mathrm{T}_{5}$ treatment were $141.21 \& 170.5,124.30 \& 103.7,28.51 \& 34.2$, and $20.75 \%$ \& $18.79 \%$ higher than $\mathrm{T}_{1}, \mathrm{~T}_{2} \mathrm{~T}_{3}$, and $\mathrm{T}_{4}$ and treatments, respectively (Fig. 4). Similarly, the highest average fruit weight $\left(110.9 \mathrm{~g}\right.$ per fruit) was measured with $\mathrm{T}_{5}$ treatment followed by $\mathrm{T}_{4}$ treatment $(105.13 \mathrm{~g}), \mathrm{T}_{3}$ 


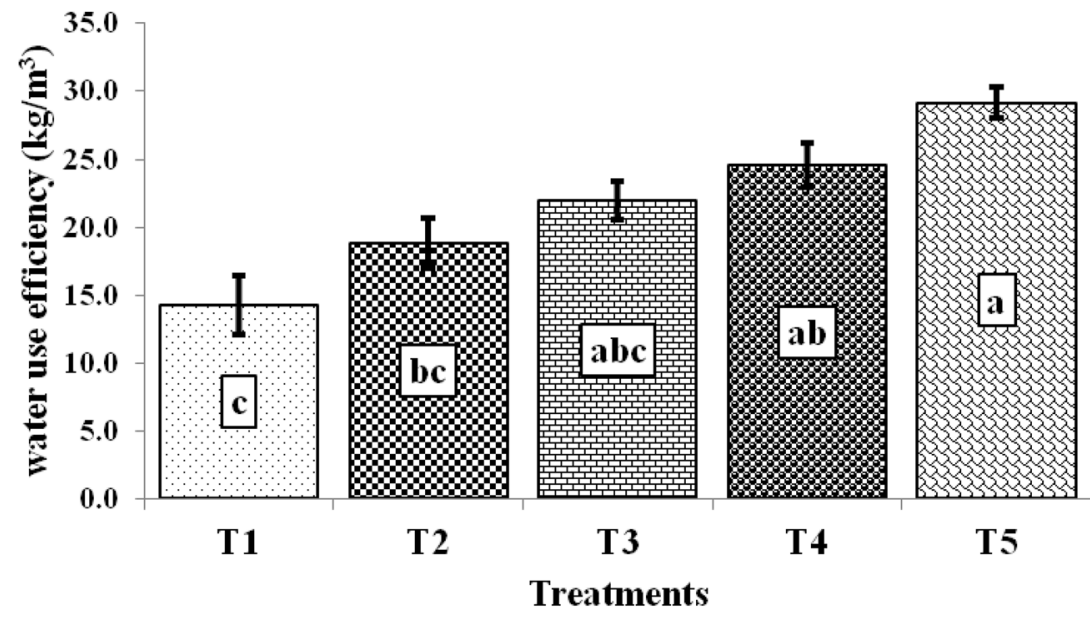

Figure 6. Water use efficiency of tomato under various treatments.

$(100.07 \mathrm{~g}), \mathrm{T}_{2}(83.90 \mathrm{~g})$, and $(75.23 \mathrm{~g})$ in $\mathrm{T}_{1}$ treatment. The tomato plants raised under $\mathrm{T}_{5}$ treatment produced $47.41,32.18,10.83$, and $5.49 \%$ more average fruit weight than $\mathrm{T}_{1}, \mathrm{~T}_{2} \mathrm{~T}_{3}$, and $\mathrm{T}_{4}$ and treatments, respectively (Fig. 5). Likewise, $\mathrm{T}_{5}$ treatment also produced the highest fruit yield ( $3.00 \mathrm{~kg}$ plant ${ }^{-1}$ or $\left.102.56 \mathrm{t} \mathrm{ha}^{-1}\right)$, which was $160.87,101.79,32.74$, and $18.89 \%$ higher fruit yield over $\mathrm{T}_{1}\left(1.15 \mathrm{~kg} \mathrm{plant}^{-1}\right.$ or $\left.39.32 \mathrm{t} \mathrm{ha}^{-1}\right), \mathrm{T}_{2}\left(1.49 \mathrm{~kg} \mathrm{plant}^{-1}\right.$ or $\left.50.83 \mathrm{t} \mathrm{ha}^{-1}\right), \mathrm{T}_{3}\left(2.26 \mathrm{~kg}\right.$ plant $^{-1}$ or $\left.77.26 \mathrm{t} \mathrm{ha}^{-1}\right)$ and $\mathrm{T}_{4}\left(2.52 \mathrm{~kg} \mathrm{plant}^{-1}\right.$ or $\left.86.27 \mathrm{t} \mathrm{ha}^{-1}\right)$ treatments, respectively (Fig. 5).

Fruit yield is a function of many independent factors like shoot length, fruit weight, number of fruits, nutrient management, pruning, training, and water use. The fruit yield was positively correlated with shoot length $(r=0.91)$, fruit weight $(r=0.76)$, dry matter content in leaves $(r=0.91)$, and water use efficiency $(r=0.96)$, and the highest fruit yield was recorded under $T_{5}$ treatment. In the integrated approach $\left(T_{5}\right)$, pruning of the tomato plants removed all food-wasting shoots, thereby improving the growth of the trellised main shoot vertically in the desired direction with regular spraying of liquid fertilizers. This enhanced the vegetative growth, shoot length, dry matter content and partitioned to developing fruit, thereby producing higher fruit yield. However, the lowest productivity in $\mathrm{T}_{1}$ treatment may be due to improper plant management, which makes the plant bushier, branchy, compact leading to humid vegetation, poor ventilation making the plants more susceptible to pests/ diseases, thereby reducing early growth than advanced treatments $\left(\mathrm{T}_{3}-\mathrm{T}_{5}\right)$. Previous studies reported similar reasoning of higher tomato yield under pruning, which improved height, fruit yield, light exposure, and better ventilation to each plant and maintained the balance between root and fruit yield over unpruned plant ${ }^{23-25}$. Trellis system of tomato shoot training coupled with pruning improved light penetration, more growing duration, ventilation, photosynthetic efficiency, and $18-25 \%$ more fruit yield ${ }^{26,27}$. In another study, higher fruit yield was obtained in tomatoes $\left(106.7 \mathrm{t} \mathrm{ha}^{-1}\right)$ with bigger-sized fruits due to a more extended harvesting period in pruned, trained, thinned tomatoes ${ }^{28}$. The dry matter production was positively correlated with fruit yield in tomatoes. In the present study, 12.5-13.0\% dry matter had been recorded in tomato shoots. Similarly, other studies found $12.84 \%$ dry matter in tomato in open condition ${ }^{29}$ and $9.3-12.5 \%$ under polyhouse condition ${ }^{30}$. The fruits are the strongest sinks of assimilates, followed by stem and roots in tomato ${ }^{31}$.

Water use efficiency (WUE). The water use efficiency $\left(\mathrm{kg} \mathrm{m}^{-3}\right)$ of tomato differed significantly among treatments (Fig. 6). The maximum WUE of tomato was observed in $\mathrm{T}_{5}$ treatment $\left(28.39 \mathrm{~kg} \mathrm{~m}^{-3}\right)$ followed by $\mathrm{T}_{4}$ treatment (26.11), $\mathrm{T}_{3}(22.07)$, whereas it was minimum (14.30) in $\mathrm{T}_{1}$ treatment. The total water applied was 275 , 270 , and $351.6 \mathrm{~mm}$ during the growing period in $\mathrm{T}_{1}, \mathrm{~T}_{2}$, and $\mathrm{T}_{3}-\mathrm{T}_{5}$ treatments, respectively. The 98.60, 39.71, 28.63, and 8.75\% higher WUE were observed under $\mathrm{T} 5$ treatment compared to $\mathrm{T}_{1}, \mathrm{~T}_{2} \mathrm{~T}_{3}$, and $\mathrm{T}_{4}$ treatments. Similarly, tomato plants grown under $\mathrm{T}_{4}$ treatment utilized water efficiently by $82.61,28.46$, and $18.28 \%$ more than $\mathrm{T}_{1}, \mathrm{~T}_{2}$, and $\mathrm{T}_{3}$ treatments. The water applied was positively correlated with shoot length $(\mathrm{r}=0.96)$ and fruit yield $(r=0.89)$. It indicated that watering to the tomato plant increased nutrient mobilization within the plant body, which increased shoot length and fruit yield. The previous study had also reported $40 \%$ higher water productivity $\left(27.82 \mathrm{~kg} \mathrm{~m}^{-3}\right)$ over control $\left(19.91 \mathrm{~kg} \mathrm{~m}^{-3}\right)$ in tomato ${ }^{32}$. In our study, the higher WUE of tomato in $\mathrm{T}_{5}$ treatment $\left(28.39 \mathrm{~kg} \mathrm{~m}^{-3}\right)$ may be due to more photosynthates formation used by developing fruit. Besides, mulching also played a significant role in minimizing evaporation loss over the traditional practice ${ }^{33}$.

Quality parameters. The chemical fruit qualities (vitamin C, lycopene, and carotenoid) of tomato varied significantly among treatments imposed on the flatbed and raised bed at farmers' fields (Fig. 7). The highest vitamin $\mathrm{C}(24.74 \mathrm{mg} / 100 \mathrm{~g})$ in tomato was found in $\mathrm{T}_{5}$, which was $4.40-17.05 \%$ higher than $\mathrm{T}_{4}-\mathrm{T}_{1}$ treatments, 5.93-12.11\% higher in $\mathrm{T}_{4}$ treatment than $\mathrm{T}_{3}-\mathrm{T}_{1}$ treatments, $3.50-5.84 \%$ higher observed with $\mathrm{T}_{3}$ treatment as compared to $\mathrm{T}_{2}-\mathrm{T}_{1}$ treatment and minimum vitamin $\mathrm{C}$ was observed with $\mathrm{T}_{1}$ treatment. Similarly, the maximum lycopene $(8.78 \mathrm{mg} / 100 \mathrm{~g})$ of tomato was observed in $\mathrm{T}_{5}$ treatment. About $11.49-23.32 \%$ higher lycopene was found in $\mathrm{T}_{4}$ treatment over $\mathrm{T}_{3}-\mathrm{T}_{1}$ treatments, 6.35-10.62\% more lycopene in $\mathrm{T}_{3}$ treatment than $\mathrm{T}_{2}$ 


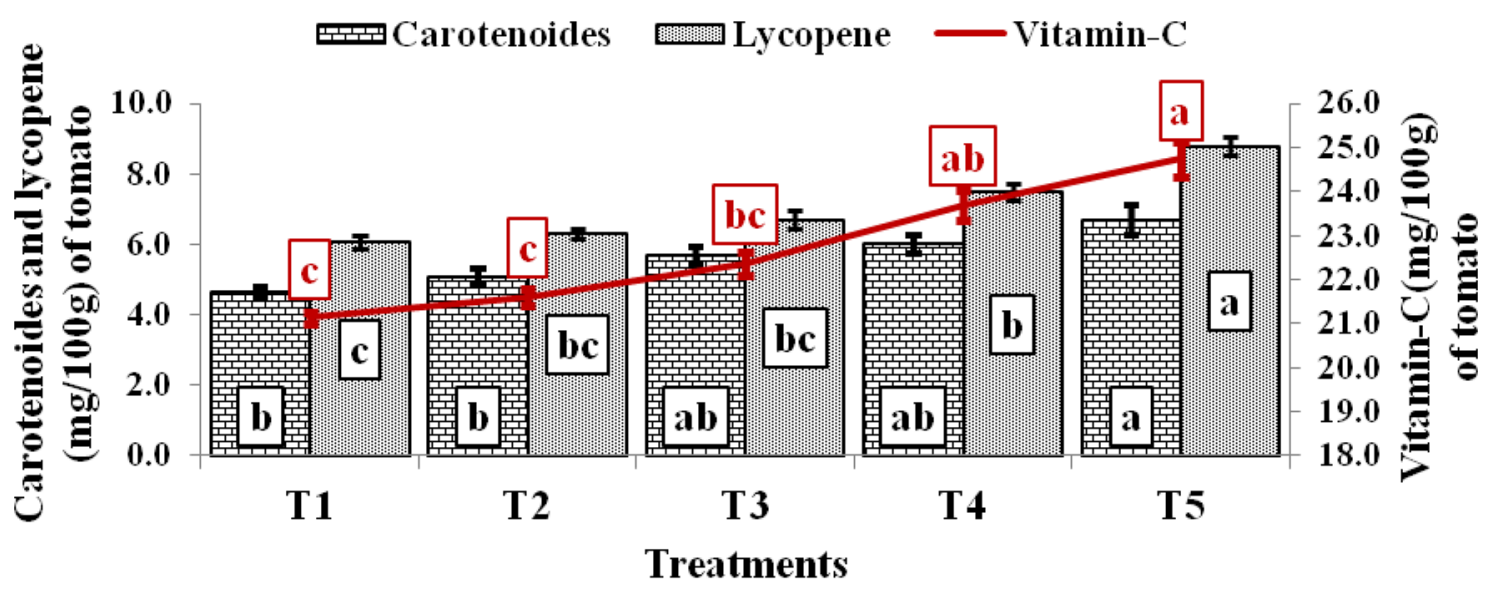

Figure 7. Fruit quality parameters of tomato under various treatments.

\begin{tabular}{|c|c|c|c|c|c|c|}
\hline Treatment & $\begin{array}{l}\text { Bacteria }(\mathrm{cfu} / \mathrm{g} \text { dry } \\
\left.\text { soil } \times 10^{6}\right)\end{array}$ & $\begin{array}{l}\text { Fungi (cfu/g dry } \\
\left.\text { soil } \times 10^{5}\right)\end{array}$ & $\begin{array}{l}\text { Actinomycetes }(\mathrm{cfu} / \mathrm{g} \\
\left.\text { dry soil } \times 10^{4}\right)\end{array}$ & $\begin{array}{l}\text { DHA ( } \mu \mathrm{g} \text { TPF released } \\
\mathrm{g} / 24 \mathrm{~h} \text { of dry soil) }\end{array}$ & $\begin{array}{l}\beta \text {-Glucosidase ( } \mu \text { g PNP } \\
\text { released/g/h of dry soil) }\end{array}$ & $\begin{array}{l}\text { Phosphatase activity } \\
\text { ( } \mu \text { g PNP released/g/h of } \\
\text { dry soil) }\end{array}$ \\
\hline $\mathrm{T} 1$ & $10.50 \pm 1.04^{c}$ & $6.33 \pm 0.88^{c}$ & $33.00 \pm 1.15^{\mathrm{c}}$ & $71.83 \pm 1.45^{\mathrm{c}}$ & $79.90 \pm 1.02^{\mathrm{c}}$ & $211.00 \pm 6.43^{\mathrm{d}}$ \\
\hline $\mathrm{T} 2$ & $11.83 \pm 1.30^{\mathrm{bc}}$ & $7.67 \pm 0.73^{c}$ & $35.33 \pm 2.03^{c}$ & $75.90 \pm 2.89^{c}$ & $83.43 \pm 2.53^{c}$ & $226.17 \pm 5.78^{d}$ \\
\hline T3 & $16.50 \pm 1.44^{\mathrm{abc}}$ & $10.00 \pm 1.15^{\mathrm{bc}}$ & $45.55 \pm 1.13^{\mathrm{b}}$ & $96.17 \pm 3.55^{b}$ & $112.60 \pm 3.29^{\mathrm{b}}$ & $313.67 \pm 4.91^{\mathrm{c}}$ \\
\hline $\mathrm{T} 4$ & $20.00 \pm 2.08^{\mathrm{ab}}$ & $15.83 \pm 1.36^{\mathrm{ab}}$ & $54.67 \pm 1.76^{\mathrm{a}}$ & $131.83 \pm 4.10^{\mathrm{a}}$ & $123.17 \pm 2.33^{\mathrm{b}}$ & $361.67 \pm 8.69^{b}$ \\
\hline T5 & $22.17 \pm 2.17^{\mathrm{a}}$ & $20.67 \pm 1.20^{\mathrm{a}}$ & $58.67 \pm 2.03^{\mathrm{a}}$ & $143.00 \pm 3.51^{\mathrm{a}}$ & $137.67 \pm 2.64^{\mathrm{a}}$ & $505.33 \pm 5.81^{\mathrm{a}}$ \\
\hline
\end{tabular}

Table 2. Soil microbial population and enzymatic activities (arithmetic mean \pm standard error) under different treatments. cfu Colony forming units, DHA Dehydrogenase activity, PNP p-nitrophenol, TPF Triphenylformazan. The values in same column followed by the same letter are not significantly different according to Tukey's Honest Test $(\mathrm{p}=0.05)$.

and $\mathrm{T} 1$ treatments, and minimum lycopene was observed with $\mathrm{T}_{1}$ treatment. Likewise, the highest carotenoid $(6.69 \mathrm{mg} / 100 \mathrm{~g})$ was observed in the $\mathrm{T}_{5}$ treatment, $11.51-44.21 \%$ higher than $\mathrm{T}_{4}-\mathrm{T}_{1}$ treatments, $5.76-29.33 \%$ higher in $\mathrm{T}_{4}$ treatment than $\mathrm{T}_{3}-\mathrm{T}_{1}$ treatments, $12.13-22.29 \%$ higher carotenoid in $\mathrm{T}_{3}$ treatment as compared to $\mathrm{T}_{2}-\mathrm{T}_{1}$ treatments and was minimum with $\mathrm{T}_{1}$ treatment. The chemical fruit qualities (vitamin $\mathrm{C}$, lycopene, and carotenoid) of tomato are very important ingredients of the human diet as these act as antioxidants in the human body, which removes free radicals formed during food digestion ${ }^{34,35}$.

Fertilization is an essential element for crop growth and development that plays an indispensable role in accumulating nutrients and aromatic volatiles ${ }^{36}$. Application of higher and additional doses of NPK couple with FYM and training/pruning in tomato improved availability of plant nutrients and growth hormones during the entire phase of growth and development fruit, which elevated photosynthates accumulation utilized by developing fruits and increased fruit yield. The synthesis of vitamin C, lycopene, and carotenoid depends mainly on photosynthates assimilation and supplies the required amount of photosynthates to the developing fruits because fruits are powerful sinks for carbohydrates ${ }^{37}$. The application of FYM improved the availability of organic acid, free amino acids, sugars, and macromolecules that are a direct precursor of synthetic sugar acids; these substances play an essential role in plant metabolism, microbial growth activities, and soil organic matter decomposition ${ }^{38}$. The phosphorus increased ascorbic acid and lycopene in the tomato fruit, even though the moderate application of nitrogen increase tomato yield ${ }^{39}$ and potassium ultimately affects quality by regulating plant carbon and nitrogen metabolism, stomatal opening and closing, enzyme activity, and photosynthetic product transport ${ }^{40}$. The pruning and training in tomato improved fruit qualities significantly because it regulated optimum plant foliage for photosynthesis to meet the carbohydrate requirement of developing fruits without waste. The application of liquid potassium dose @ $4.5 \mathrm{~g}$ per liter had significantly improved photosynthesis, enzyme activation, cell turgor maintenance, which had also been observed and reported earlier ${ }^{41}$. The integration of FYM with mulching, training/pruning, and liquid fertilizers improved fruit yield with optimum fruit size and fruit quality parameters.

Microbial population and enzymatic activities of soil. The microbial population (bacteria, fungi, and actinomycetes) and enzymatic activities (dehydrogenase, $\beta$-glucosidase, and phosphatase) of soil varied significantly among treatments (Table 2 ). The highest microbial population of bacteria, fungi, and actinomycetes were observed as $22.17,20.67$, and $58.67 \mathrm{CFU} \mathrm{g}^{-1}$ of dry soil in the case of $\mathrm{T}_{5}$ treatment, which was 10.83-111.11, 30.53-226.32, and 7.32-77.78\% higher compared to $\mathrm{T}_{4}, \mathrm{~T}_{3}, \mathrm{~T}_{2}$, and $\mathrm{T}_{1}$ treatments, respectively. Similarly, soil enzymatic activities viz. dehydrogenase, $\beta$-glucosidase, and phosphatase in the soil were recorded maximum $(143,137.67$, and 505.33) with T5 treatment, which registered 8.47-99.07, 11.77-72.30, and 39.72-139.49\% higher enzymatic activities in the soil in comparison to $\mathrm{T}_{4}, \mathrm{~T}_{3}, \mathrm{~T}_{2}$, and $\mathrm{T}_{1}$ treatments, respectively. Organic 


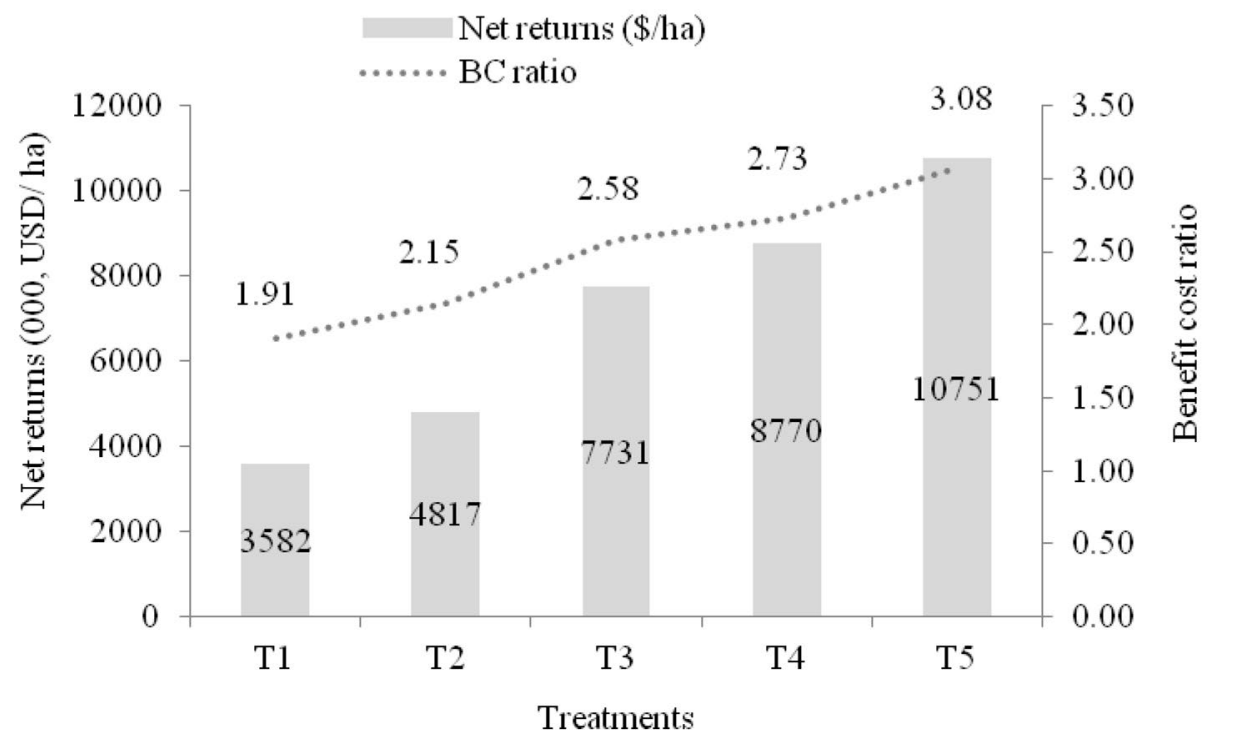

Figure 8. Net returns and BCR of tomato under various treatments.

manure, tomato management practices (training and pruning), and liquid fertilizers increased biomass production, which added higher soil organic matter that increased enzymatic activities. The highest microbial population was recorded in $\mathrm{T}_{5}$ treatment because it was supplemented with a maximum dry matter of tomato (19.95 $\mathrm{t} \mathrm{ha}^{-1}$ ) in the field coupled with farmyard manure (@10.0 $\mathrm{t} \mathrm{ha}^{-1}$ ) that provided an adequate amount of food to the microorganisms, which proliferated efficiently in the soil under ambient conditions in the mulched plots. Previous studies ${ }^{42,43}$ also reported higher microbial masses of bacteria, fungi, and actinomycetes in the plots that received farmyard manure integrated with solid fertilizers and green manures. The use of liquid fertilizers integrated with farmyard manure also helped improve the microbial population due to soil conditioning with the organic source. Similarly, enzymatic activities were also recorded highest in the $\mathrm{T}_{5}$ treatment due to higher biomass recycling coupled with farmyard manure in the field, which increased soil enzymatic activities. Soil enzyme activities also improved under integrated nutrient management $\left(\mathrm{T}_{5}\right.$ treatment) that received elevated doses of organic manure coupled with training, pruning, and liquid fertilizer application because it provided additional food supply of organic matter under the favourable condition to the microbes compared to farmer practice $\left(\mathrm{T}_{1}-\mathrm{T}_{2} \text { treatments }\right)^{44-49}$.

Profitability. The net return among various treatments showed an increasing trend from $\mathrm{T}_{1}$ to $\mathrm{T}_{5}$ treatments. The highest net return (10.75 thousand USD ha ${ }^{-1}$ ) was recorded with $\mathrm{T}_{5}$ treatment followed by $\mathrm{T}_{4}(8.77)$, $\mathrm{T}_{3}$ (7.73), $\mathrm{T}_{2}$ (4.82), and minimum with $\mathrm{T}_{1}$ treatment ( 3.58 thousand USD ha ${ }^{-1}$ ). The benefit-cost ratio (BCR) of different treatments of pruning, trellising, liquid fertilizer application was calculated and shown in Fig. 8. The highest BCR (3.08) was recorded in $\mathrm{T}_{5}$ treatment followed by $\mathrm{T}_{4}(2.73), \mathrm{T}_{3}(2.58), \mathrm{T}_{2}(2.15)$, and minimum with $\mathrm{T}_{1}$ treatment (1.91). The BCR indicated that all the treatments were beneficial to the growers as the return was higher than investment, but farmer practice ( $T_{1}$ and $T_{2}$ treatments) realized low BCR than improved practices $\left(\mathrm{T}_{3}, \mathrm{~T}_{4}\right.$, and $\left.\mathrm{T}_{5}\right)$. From the economic point of view, it is apparent from the above results that the treatment $\mathrm{T}_{5}$ was more profitable compared to other treatments. Some authors also observed higher BCR (3.7) under different nutrient levels, pruning and training system of tomato ${ }^{50,51}$. The net return ranged from 7.95 to 11.06 thousand USD obtained from the combination of technologies in tomato compared to traditional farming practices (3.58-4.82 thousand USD). A previous study also showed higher profitability in pruned and staked tomato ${ }^{10}$. The marketable produce harvested was more in advanced treatment $\left(\mathrm{T}_{3}-\mathrm{T}_{5}\right)$ over farmers' practice due to balanced nutrient management, aeration in the plant canopy, better photosynthesis by the plant foliage, and its distribution to all developing fruits.

Principal component analysis and hierarchical clustering analysis. The principal component analysis was also done as a dimension reduction technique to evaluate the treatment effect on growth/productivity parameters and microbial population / enzymatic soil activities (Table 3A-B). Firstly, principal component analysis (PCA) was done on 7 parameters. The first principal component was selected using the eigenvalue criteria ( $>1$ ), which explain $97.05 \%$ of the total variance (with communality value $\geq 0.910$ ) of 7 growth/production parameters. In the principal component 1 , the highest contribution in terms of factor loading was given by dry matter and carotenoid (0.997), and the lowest contribution yielded by lycopene content (0.954) with performance order dry matter $=$ carotenoid $>$ fruit yield $>$ shoot length $>$ vitamin $C>$ fruit weight $>$ lycopene content. The contributions of the individual growth parameters were expressed in one component model given in Fig. 9A, PC 2 has not contributed significantly (eigenvalue $<1$ ) but had been included in the PCA graph for better interpretation. 


\begin{tabular}{|l|l|l|l|l|l|}
\hline A & PC1 & Communality & Parameter & PC1 & Communality \\
\hline Parameter & 0.996 & 0.992 & Bacteria & 0.995 & 0.99 \\
\hline Fruit yield (FY) & 0.982 & 0.964 & Fungi & 0.985 & 0.97 \\
\hline Fruit weight (FW) & 0.986 & 0.972 & Actinomycetes & 0.994 & 0.99 \\
\hline Shoot length (SL) & 0.997 & 0.994 & DHA & 0.990 & 0.98 \\
\hline Dry matter (DM) & 0.954 & 0.910 & Glucosidase & 0.988 & 0.98 \\
\hline Lycopene content (LC) & 0.984 & 0.968 & Phosphtase & 0.976 & 0.95 \\
\hline Vitamin-C & 0.997 & 0.994 & Eigenvalue & 5.86 & \\
\hline Carotenoids & 6.793 & - & \% variance & 97.62 & - \\
\hline Eigen value & 97.05 & & & & \\
\hline \% variance explained & & & &
\end{tabular}

Table 3. Results of principal component analysis (PCA) showing principal components (PC) with their Eigenvalues and proportion of variance (in percent) explained, along with rotated factor loadings and communalities growth/productivity parameters (A) and for microbial population and enzymatic activities related parameters $(\mathrm{B})$.
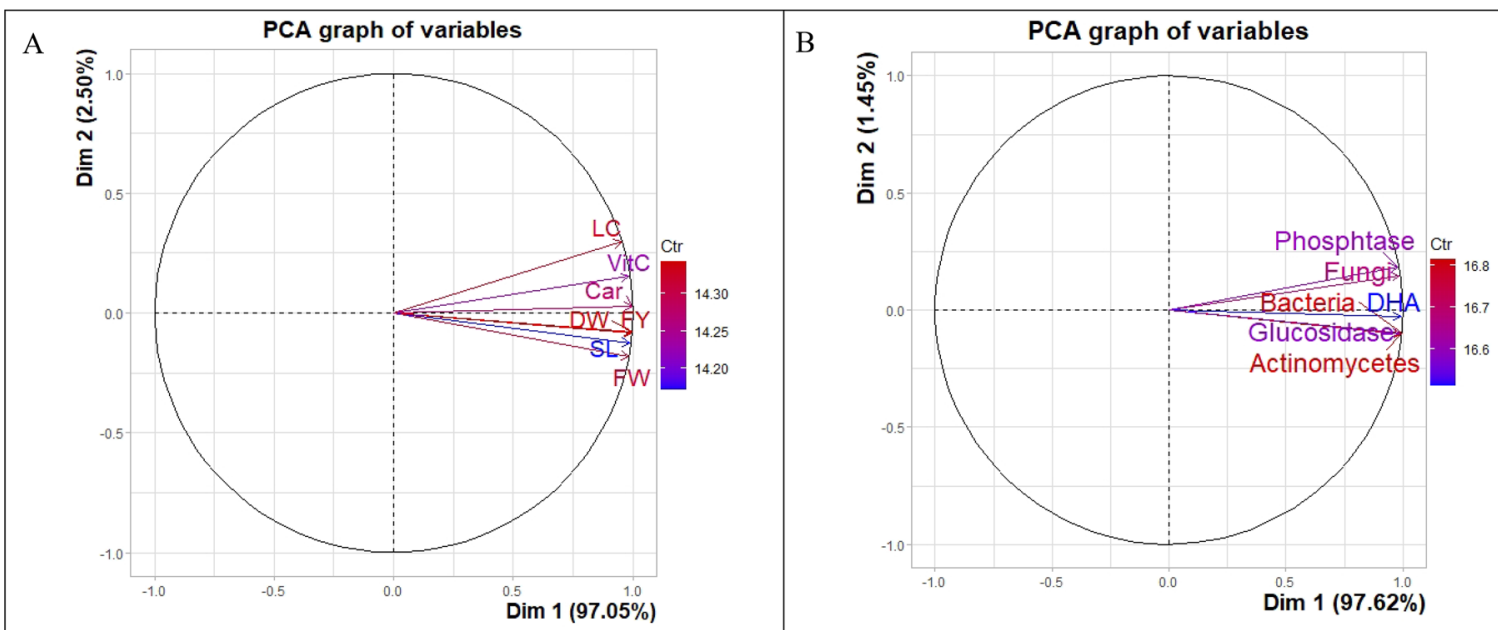

Figure 9. (A) Principal component analysis (PCA) represents the contribution of growth parameters/ productivity-related parameters on PC1 and PC2. (B) Principal component analysis (PCA) represents the microbial population's contribution and enzymatic activities-related parameters on PC1 and PC2.

Again the principal component analysis (PCA) was conducted on the six selected microbial population/ enzymatic activities related parameters (bacteria, fungi, actinomycetes, dehydrogenase, glucosidase, and phosphatase) to screen the treatment effect $\left(\mathrm{T}_{1}-\mathrm{T}_{5}\right)$ on microbial population/enzymatic activities. The first principal component was selected using the eigenvalue criteria $(>1)$, which explain $97.62 \%$ of the total variance (with communality value $\geq 0.950$ ) of 6 microbial population/enzymatic activities of soil. In the principal component 1 , the highest contribution in terms of factor loading was given by bacteria (0.995) and lowest contribution reflected by phosphatase $(0.976)$ with performance order bacteria $>$ actinomycetes $>$ dehydrogenase $>$ glucosidase $>$ fungi $>$ phosphatase. The contributions of the individual parameter (microbial population/enzymatic activities) were expressed in one component model given in Fig. 9B where though cont contributed significantly (eigenvalue $<1$ ) yet shown in the PCA graph for better understanding to know the performance of parameters.

The hierarchical clustering analysis (HCA) using PC1 (generated through principal component analysis of 7 growth parameters) was also carried out for grouping of homogeneous treatment and treatment ranking (Fig. 10A,B). The Individual factor map of different treatments $\left(\mathrm{T}_{1}-\mathrm{T}_{5}\right)$ ranked the treatments as 1 st $(\mathrm{T} 5)>2 \mathrm{nd}$ (T4) $>3 \mathrm{rd}$ (T3) $>4$ th $(\mathrm{T} 2)>5$ th $\operatorname{rank}$ (T1) based on contribution on PC1 (Fig. 10A). The dendrogram obtained from hierarchical cluster analysis of PC1 (Fig. 10B) where cluster 1 with lowest treatment effects contains $\left(\mathrm{T}_{1}\right.$ and $\mathrm{T}_{2}$ ), Cluster 2 with moderate treatment effects contains $\left(\mathrm{T}_{3}\right.$ and $\left.\mathrm{T}_{4}\right)$, and cluster 3 with highest treatment effects contains only $\left(\mathrm{T}_{5}\right)$. Similarly, the hierarchical clustering analysis (HCA) using PC1 (generated through principal component analysis of 6 soil-related parameters) was also carried out for grouping of homogeneous treatment and treatment ranking (Fig. 10C,D). The Individual factor map of different treatments $\left(\mathrm{T}_{1}-\mathrm{T}_{5}\right)$ ranked shown a similar pattern already reported in growth/productivity parameters (Fig. 10C). The dendrogram structure of hierarchical cluster analysis obtained was also more or less similar to growth/productivity parameters except for $\mathrm{T}_{4}$ treatment, which shifted from cluster 2 (moderate) to cluster 3 (highest) of PC1 (Fig. 10D). 


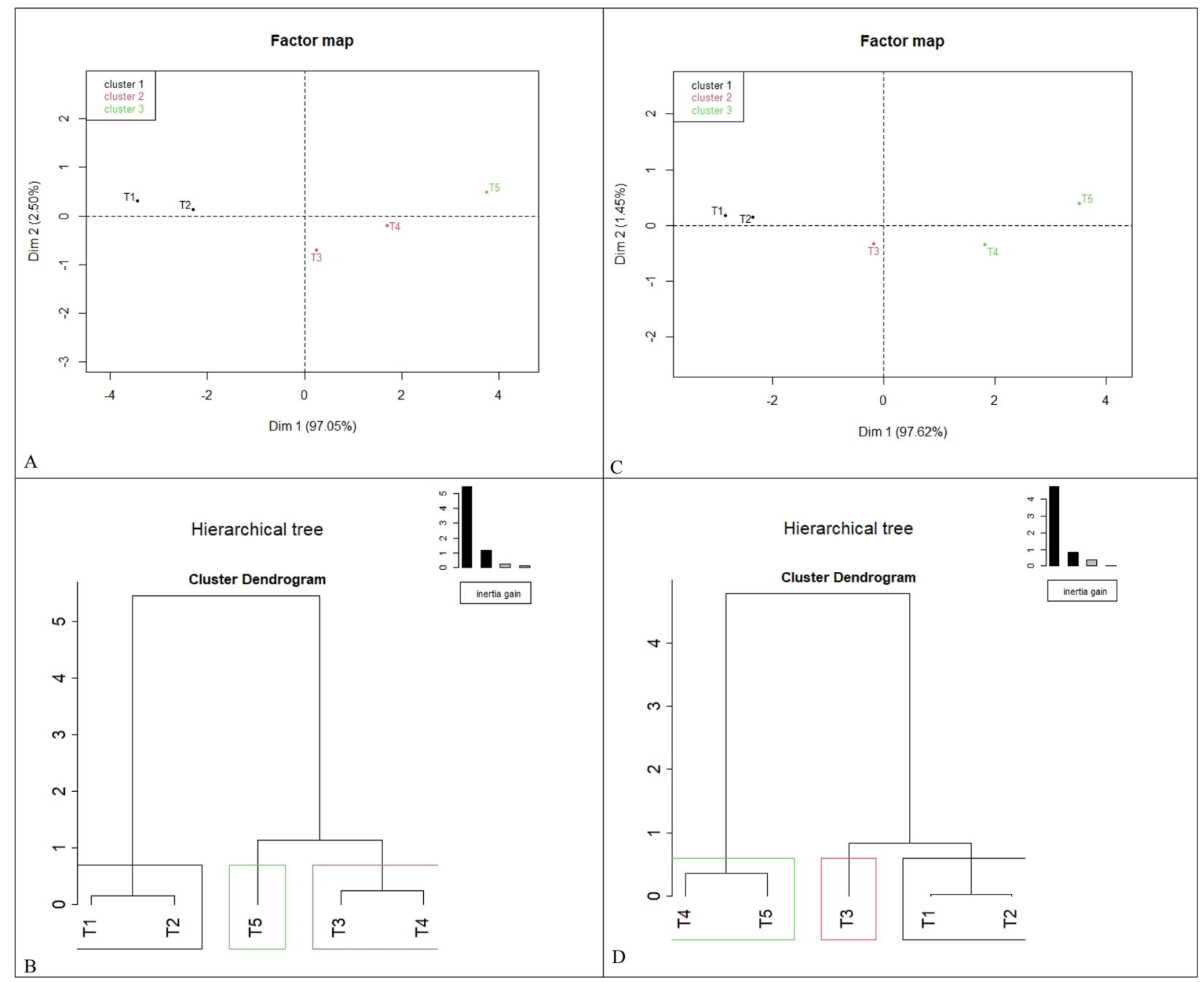

Figure 10. (A): Individual factor map of different treatments $\left(\mathrm{T}_{1}-\mathrm{T}_{5}\right)$ using principal component analysis (PCA) for growth/productivity related parameters, (B) Dendrogram obtained by hierarchical cluster analysis (HCA) using PC1 of PCA for growth/productivity related parameters (C) Individual factor map of different treatments $\left(\mathrm{T}_{1}-\mathrm{T}_{5}\right)$ using principal component analysis (PCA) for microbial population and enzymatic activities related parameters, (D) Dendrogram obtained by hierarchical cluster analysis (HCA) using PC1 of PCA of microbial population and enzymatic activities related parameters.

\section{Conclusion}

This study on tomato was conducted to improve productivity, quality, and net returns through plant architectural modification such as trellising and pruning and liquid fertilizer use. The integrated approach, i.e. $\mathrm{T}_{5}$ (trellising, pruning, and liquid fertilizers in tomato grown on a raised bed with polythene mulch) improved fruit yield, shoot length, dry matter content, water productivity, vitamin C, carotenoid, lycopene with a net return of 10.75 thousand USD ha-1 in comparison to farmer practice. Therefore, an integrated approach is beneficial to the farmers for higher production with quality fruits and net returns. However, it is imperative to gain knowledge and expertise in trellising and pruning with liquid fertilizers to achieve a higher fruit yield with a better tomato quality. This integration approach of trellising, pruning and liquid fertilizers will improve farmers' economic status and reduce pests and diseases in the field by providing well-placed plants, branches, and fruits. The clustering and ranking of all the parameters and treatments also confirmed the superiority of the integrated approach over other treatments in terms of tomato fruit production and quality.

Received: 28 October 2020; Accepted: 7 July 2021

Published online: 20 September 2021

\section{References}

1. FAOSTAT. http://www.fao.org/faostat/en/\#home. Accessed 24 Aug 2020.

2. Horticulture statistics at a glance 2018, GOI, MOAFW, DACFW, Horticulture Statistics Division. http://www.agricoop.nic.in/.

3. Singh, V. K., Rajan, S., Singh, A. \& Soni, M. K. Protected cultivation of horticultural crops. Precision farming development centre, ICAR-CISH, Lucknow. Tech. Bull. 1, 1-16 (2015). 
4. Almeida, L. H. C. D., Fratoni, M. M. J., Fregonezi, G. A. D. F. \& Takahashi, H. W. Nutritional assessment of potassium in tomato (Lycopersicon esculentum Mill.) by direct reading of fruit sap. Afric. J. Agril. Res. 11(14), 1245-1256 (2016).

5. Cox, B. Training Systems and Pruning in Organic Tomato Production. (Extension. 2015). http://articles.extension.org/pages/ $18647 /$

6. Ahmad, A. \& Singh, A. Effects of staking and row-spacing on the yield of tomato (Lycopersicon lycopersicum Mill.) cultivar Roma VF in the Sokoto Fadama, Nigeria. Nig. J. Hort. Sci. 10, 94-98 (2005).

7. Kanyomeka, L. \& Shivute, B. Influence of pruning on tomato production under controlled environments. Agric. Trop. Subtrop. 38(9), 79-83 (2005).

8. Thakur, O., Kumar, V. \& Singh, J. A review on advances in pruning to vegetable crops. Int. J. Curr. Microbiol. App. Sci. 7(02), 3556-3565 (2018)

9. Lin, Y. et al. Bio-organic fertilizer with reduced rates of chemical fertilization improves soil fertility and enhances tomato yield and quality. Sci. Rep. 10(177), 1-10 (2020).

10. Baligar, V. C., Fageria, N. K. \& He, Z. L. Nutrient use efficiency in plants. Commun. Soil Sci. Plant Anal. 32(7-8), 921-950 (2001).

11. Kowalska, I. Nutrient and water uptake in different stages of maturity of greenhouse tomato grown on NFT at different sulphate levels in nutrient solution. Acta Sci. Pol. Hortorum Cultus. 2(2), 43-50 (2003).

12. Oded, A. \& Uzi, K. Enhanced performance of processing tomatoes by potassium nitrate based nutrition. Acta Hort. 613, 81-87 (2003).

13. Mermoud, A., Tamini, T. D. \& Yacouba, H. Impacts of different irrigation schedules on the water balance components of an onion crop in a semi-arid zone. Agril. Water Manage. 77(1-3), 282-295 (2005).

14. Ranganna, S. Handbook of Analysis and Quality Control for Fruit and Vegetable Products. (Tata McGraw-Hill Education, 1986). ISBN 0074518518.

15. Walkley, A. J. \& Black, I. A. An examination of the Degtjareff method for determining soil organic matter and a proposed modifcation of the chromic acid titration method. Soil Sci. 37, 29-38 (1934).

16. Bremner, J. M. Nitrogene-total. in Methods of Soil Analyses, Part III, (Chemical Methods et al.) SSSA, 1085-1184. (1996).

17. McLean, E. O. Soil pH and lime requirement. In Methods of Soil Analysis, Part 2 Chemical and Microbiological Properties 2 nd edn (eds Page, A. L. et al.) 199-224 (Academic Press, 1982).

18. Booth, C. Introduction to general methods. In Methods in Microbiology Vol. 4 (ed. Booth, C.) 1-47 (Academic Press, 1971).

19. Casida, L. E., Klein, D. A. \& Sanoto, T. Soil dehydrogenase activity. Soil Sci. 98, 371-376 (1964).

20. Eivazi, F. \& Tabatabai, M. A. Phosphatases in soils. Soil Biol. Biochem. 9, 167-172 (1977).

21. Tabatabai, M. A. \& Bremner, J. M. Use of para-nitrophenyl phosphate for assay of soil phosphatase activity. Soil Biol. Biochem. 1, 301-307 (1969).

22. Johnson, R. A. \& Wichern, D. W. Applied Multivariate Statistical Analysis Vol. 6 (Pearson, 2007).

23. Patil, V. K., Gupta, P. K. \& Tombre, P. O. Influence of pruning, mulching and nitrogenous fertilizer on the growth, yield and quality of staked plants of sioux variety of tomato. Proc. Veg. Grower. 8, 4-9 (1973).

24. Preece, J. E. \& Read, P. E. The Biology of Horticulture 2nd edn. (Wiley, 2005).

25. Sultana, R., Dilruba, S., Parveen, K., Kulsum, U. \& Parvin, N. Effect of pruning on growth and yield of tomato (Lycopersicon esculentum Mill.). Eur. Int. J. Sci. Tech. 5(9), 127-132 (2016).

26. Chen, J. T. \& Lal, G. Pruning and Staking Tomatoes (International Cooperator's Guide, 1999).

27. Adelana, B. O. Effect of Staking on Growth and Yield of Tomatoes. East Afr. Agril. For. J. 41(3), 243-249 (1979).

28. Roquejani, M. S., Melo, A. M. T., Shirahige, F. H., Melo, P. C. T. \& Purquerio, L. F. V. Produtividade e qualidade de híbridos de tomate dos segmentos italiano e santa cruz em ambiente protegido. in FAPESP. Anais eletrônicos. http://www.iac.sp.gov.br/aread oinstituto/pibic/anais/2008/Artigos/RE0800020.pdf.

29. Akand, H., Mazed, H. E. M. K., Haque, N., Partho, S. G. \& Pulok, A. I. Effect of potassium and stem pruning on growth and yield of tomato (Lycopersicon esculentum Mill.). Int. Multidisc. 3(12), 30-43 (2014).

30. Heuvelink, E. Tomato growth and yield: quantitative analysis and synthesis. Dissertation, Wageningen Agricultural University, Wageningen (1996).

31. Cockshull, K. E. \& Ho, L. C. Regulation of tomato fruit size by plant density and truss thinning. J. Hort. Sci. 70, 395-407 (1995).

32. Liu, J., Hu, T., Feng, P., Wang, L. \& Yang, S. Tomato yield and water use efficiency change with various soil moisture and potassium levels during different growth stages. PLoS ONE 14(3), e0213643 (2019).

33. Kumar, S. \& Dey, P. Effects of different mulches and irrigation methods on root growth, nutrient uptake, water use efficiency and yield of strawberry. Sci. Hort. 127(3), 318-324 (2011).

34. Rajendra, S. R. \& Patil, V. K. Flowering and fruiting of some important varieties of tomato as affected by spacing, staking and pruning. Ind. J. Agril. Sci. 499(5), 358-360 (1979).

35. Levy, J. \& Sharoni, Y. The function of tomato Lycopene and its role in human health. HerbalGram 62, 49-56 (2004).

36. Kaur, H., Bedi, S., Sethi, V. P. \& Dhatt, A. S. Effects of substrate hydroponic systems and different N and K ratios on yield and quality of tomato fruit. J. Plant Nutr. 41, 1547-1554 (2018).

37. Lester, G. E., Jifon, J. L. \& Rogers, G. Supplemental foliar potassium applications during muskmelon fruit development can improve fruit quality, ascorbic acid, and beta-carotene contents. J. Am. Soc. Hort. Sci. 130, 649-653 (2005).

38. Xu, X. K., Luo, X. B., Jiang, S. H. \& Xu, Z. J. Biodegradation of dissolved organic carbon in soilextracts and leachates from a temperate forest stand and its relationship to ultraviolet absorbance. Chin. Sci. Bull. 57(8), 912-920 (2012).

39. Dumas, Y., Dadomo, M., Dilucca, G. \& Grolier, P. Effects of environmental factors and agricultural techniques on antioxidant content of tomatoes. J. Sci. Food Agric. 83, 369-382 (2003).

40. Wang, X. \& Xing, Y. Evaluation of the effects of irrigation and fertilization on tomato fruit yield and quality: A principal component analysis. Sci. Rep. 7(350), 1-13 (2017).

41. Marschner, H. Mineral Nutrition of Higher Plants 3rd edn. (Academic Press, 2011).

42. Kanazawa, S., Susumu Asakawa, A. \& Takai, Y. Effect of fertilizer and manure application on microbial numbers, biomass, and enzyme activities in volcanic ash soils. Soil Sci. Plant Nutr. 34(3), 429-439 (1988).

43. Basha, S. J., Basavarajappa, R., Geeta Shirnalli, G. \& BabaladSoil, H. B. Microbial dynamics and enzyme activities as influenced by organic and inorganic nutrient management in vertisols under aerobic rice cultivation. J. Environ. Biol. 38, 131-138 (2017).

44. Watts, D. B., Allen, T. H., Feng, Y. \& Prior, S. A. Soil microbial community dynamics as influenced by composted dairy manure, soil properties, and landscape position. Soil Sci. 175, 474-486 (2010).

45. Feng, X. et al. Soil ionomic and enzymatic responses and correlations to fertilizations amended with and without organic fertilizer in long-term experiments. Sci. Rep. 6, 24559. https://doi.org/10.1038/srep24559 (2016).

46. Meena, V. S. et al. Microbial dynamics as influenced by concentrate manure and inorganic fertilizer in alluvium soil of Varanasi, India. Afr. J. Microbiol. Res. 8, 257-263 (2014).

47. Bohem, L., Langer, U. \& Bohem, F. Microbial biomass, enzyme activities and microbial community structure in two European longterm field experiments. Agric. Ecosyst. Environ. 109, 141-152 (2005).

48. Ozlu, E. et al. Soil health indicators impacted by long-term cattle manure and inorganic fertilizer application in a corn-soybean rotation of South Dakota. Sci. Rep. 9, 11776 (2019).

49. Pertile, M. et al. Responses of soil microbial biomass and enzyme activity to herbicides imazethapyr and flumioxazin. Sci. Rep. 10, 7694. https://doi.org/10.1038/s41598-020-64648-3 (2020). 
50. Mazed, H. E. M. K., Akand, H., Haque, N., Pulok, A. I. \& Partho, S. G. Yield and economic analysis of tomato (Lycopersicon esculentum Mill.) as influenced by potassium and stem pruning. Int. J. Sci. Res. Publ. 5(1), 1-5 (2015).

51. Burgis, D. S. \& Levins, R. A. Pruning determinate tomato plants will increase dollar return. Proc. Florida State Hort. Soc. 87, $122-124$ (1974).

\section{Acknowledgements}

This work was conducted at farmer's field under Tribal Sub-Plan budget funded by ICAR-Indian Institute of Soil and Water Conservation, 218 Kaulagarh Road, Dehradun, Uttarakhand, for increasing farmer's income through improving the productivity of tomato with innovative integration of technologies. We thank all the farmers for giving their consents and perimission to conduct this study on their agricultural fields. We also thankfully acknowedge the technical assistance of Mr. Ravish Kumar, Mr. Chatar Singh and Priyanka Khantwal for collecting the data and analysis in Plant Science laboratory and at farmers' field.

\section{Author contributions}

A.C.R., H.M., C.S. Conceptualized the research and design the experiments; A.C.R., P.K.,. L.C., C.S., V.K.D. Contribute to experimental materials and H.M.,. A.C.R., P.K.,. J.J., executed the field experiments and data collection; A.K.G., A.C.R., J.J. analyzed the soil and microbial samples; S.I., S.K.K., S.P. interpretation and analyzed data; A.C.R., S.I., S.K.K., S.P., P.K., V.K.D. prepared the manuscript, H.M., P.R.O., R.S.Y. edited the manuscripts and M.M. for guidance and support as director of the institute.

\section{Competing interests}

The authors declare no competing interests.

\section{Additional information}

Correspondence and requests for materials should be addressed to A.C.R.

Reprints and permissions information is available at www.nature.com/reprints.

Publisher's note Springer Nature remains neutral with regard to jurisdictional claims in published maps and institutional affiliations.

(c) Open Access This article is licensed under a Creative Commons Attribution 4.0 International

License, which permits use, sharing, adaptation, distribution and reproduction in any medium or format, as long as you give appropriate credit to the original author(s) and the source, provide a link to the Creative Commons licence, and indicate if changes were made. The images or other third party material in this article are included in the article's Creative Commons licence, unless indicated otherwise in a credit line to the material. If material is not included in the article's Creative Commons licence and your intended use is not permitted by statutory regulation or exceeds the permitted use, you will need to obtain permission directly from the copyright holder. To view a copy of this licence, visit http://creativecommons.org/licenses/by/4.0/.

(c) The Author(s) 2021 